\title{
British Colonial Knowledge and the Hajj in the Age of Empire
}

\author{
John Slight
}

\section{Introduction}

Europeans produced and accumulated a vast body of information on the peoples, societies and polities they encountered, and, in many cases, came to rule over during the age of empire. This material was recorded in numerous formats, including maps, account-books, official reports, censuses, gazetteers, published books and pamphlets, and by a wide variety of authors, including consuls, colonial officials, travellers, doctors, and missionaries. Islam was an important subject of enquiry for Europeans engaged in this information gathering. ${ }^{1}$ Given the size and number of Muslim polities, and the geographical spread and demographic strength of Muslims from West Africa to Southeast Asia, this was unsurprising. ${ }^{2}$ Many of Islam's religious practices attracted European attention for a number of purposes - scholarly, ethnographic, economic — and often intersected with colonial administration, such as the municipal regulation of what were termed 'Muslim festivals', such as 'Id al-Fitr. ${ }^{3}$

But the scale and scope of the Hajj set it apart from Islam's other religious practices as a subject and object of enquiry for Europeans. The Hajj is the largest annual gathering of people on the planet for a religious purpose. Every year during the imperial era, hundreds of thousands of men and women, many of whom were colonial subjects, made the momentous decision to leave their homes across Africa and Asia to set out on the often long journey to the Hijāz, and the Holy City of Mecca, to perform the Hajj, the fifth pillar of Islam. This chapter focuses on the efforts to obtain, collate, and interpret information on the Hajj by officials working for the British Empire. Beginning in the 187os,

1 David Motadel, "Introduction," in Islam and the European Empires, ed. David Motadel (Oxford: Oxford University Press, 2014), 1-34, 26-30.

2 Ira M. Lapidus, A History of Islamic Societies (Cambridge: Cambridge University Press, 1988).

3 See for example Garcin de Tassy, Mémoire sur des particularités de la religion, Musulmane dans l'Inde, d'après les ouvrages Hindoustani (Paris: De l'imprimerie royale, 1831). For the Hajj, a foundational work is F.E. Peters, The Hajj (Princeton, N.J.: Princeton University Press, 1994). 
when Britain's engagement with the Hajj hugely expanded due to the opening of the Suez Canal and the threat of epidemic diseases linked to pilgrims' movements, the chapter ends on the eve of the Second World War, which marks a caesura in the pilgrimage's history, on the cusp of a world in which postcolonial nation states, oil production, and air travel dramatically transformed the Hajj experience. ${ }^{4}$

This chapter focuses on the British Consulate in Jeddah, the nearest port to Mecca where the majority of colonial pilgrim-subjects arrived and departed from. Jeddah contained the consulates of several European powers in this period, such as France, Russia and the Netherlands, as well as other powers with Muslim subjects, such as Persia. ${ }^{5}$ The principal forms of information produced by Britain on the pilgrimage from the late 1860 s were the annual reports on the Hajj, which form this chapter's principal source-base. ${ }^{6}$ The chapter will chart how British knowledge production changed over time, being affected by wider concerns that ranged from the threat of epidemic disease and political changes in the Hijāz, such as the shifts from Ottoman to Hashemite then Saudi control. These moments of flux often dictated the content of information gathered on the pilgrimage and the way in which this material was interpreted and presented in official reports.

Through a critical analysis of these archival sources, the chapter will argue that the Muslim employees of the Jeddah Consulate played a vital role in the production of British knowledge related to the Hajj. Many Hajj reports were authored by Muslim Vice-Consuls. Although numerous Hajj reports carried the imprimatur of the British Consul, substantial parts of the information contained within these documents had been sourced from the Muslim ViceConsul and his interlocutors, who included pilgrims and the inhabitants of Jeddah, Mecca and Medina. The chapter will demonstrate how information was received, interpreted and presented by the British consulate in Jeddah in its reports to officials in London and elsewhere in Britain's Muslim empire, especially in India, which accounted for the largest number of Britain's pilgrimsubjects. As Eric Tagliacozzo has stated, British official documents "give a real sense collectively of how the British Empire conceptualised the Hajj through

4 Britain's engagement with the Hajj is detailed in John Slight, The British Empire and the Hajj, 1865-1956 (Cambridge, MA: Harvard University Press, 2015).

5 Ulrike Freitag, "Helpless Representatives of the Great Powers? Western Consuls in Jeddah, 1830s to 1914," Journal of Imperial and Commonwealth History 40.3 (2012): 357-381.

6 Records of the Hajj, Volumes 1-10, Alan Rush ed. (Slough: Archive Editions, 1993), hereafter cited in abbreviated form as $\mathrm{RoH}$ and the relevant volume number. 
the lens of the 'official mind'". ${ }^{7}$ Yet long-standing concepts of imperialism's 'official mind' need revision, to account for the fact that, despite imbalances of power, these Muslim employees also formed part of this 'official mind' in relation to British knowledge of the Hajj, and imperial policies towards the ritual. $^{8}$

The remainder of the chapter places the example of knowledge production at the British Consulate in Jeddah in a wider colonial context by examining the simultaneous production of Hajj reports in Bombay, the main port of departure for Indian pilgrims. This corpus of knowledge built up by consular and colonial state entities is then considered alongside a number of non-official sources, such as Richard Burton's Pilgrimage to Al-Medinah and Meccah (1855-1856), to consider how influential such sources were on official understandings of the Hajj.

European interactions with the Hajj formed an important part of EuropeanMuslim relations in the age of empire. Britain's Hajj reports made an important contribution to official British understandings of, and interactions with, the ritual. This chapter's analysis of the Hajj reports contributes to studies of European knowledge of Islam in the age of empire, and responds to David Motadel's call that there is a "need for further systematic exploration of official government documents ... which concern Islam." ${ }^{\prime 9}$

\section{Colonial Knowledge, Islam, and the Hajj}

There has been extensive scholarship on colonial knowledge as an important component in understanding the nature of empire and imperialism..$^{10}$ Studies have pioneered deconstructive and critical readings of colonial sources in contrast to traditional imperial history that approached such texts instrumen-

$7 \quad$ Eric Tagliacozzo, The Longest Journey: Southeast Asians and the pilgrimage to Mecca (New York: Oxford University Press, 2013), 11.

8 Ronald Robinson and John Gallagher with Alice Denny, Africa and the Victorians: the official mind of imperialism (London: Macmillan, 1961).

9 David Motadel, "Islam and the European Empires," Historical Journal 55.3 (2012): 831-856, 856 .

10 Motadel, "Introduction," 26. Much scholarship on colonial knowledge relates to South Asia. On colonial knowledge and Africa, and other types of colonial knowledge production in the fields of cartography, medicine and science, see Tony Ballantyne, "Colonial knowledge," in The British Empire: themes and perspectives, ed. Sarah Stockwell (Oxford: Blackwell Publishers, 2008), 177-198, 184-185, 187 . 
tally as objective and factually correct. ${ }^{11}$ Key works in this field include that of Michel Foucault on discourse and the power-knowledge nexus, and Edward Said's Orientalism, which viewed the discipline and practice of Orientalism as a system of knowledge production that created hierarchical oppositions between Europe and the 'Other,' emphasising the power of representation for the sake of colonial domination. ${ }^{12}$ Gayatri Spivak raised a further important critique of the colonial archival record, stating that people only appeared in it when they were needed to further the aims of the coloniser. ${ }^{13}$ In these interpretations, colonial knowledge was produced to enable economic exploitation, conquest and colonisation; little can be retrieved from these sources beyond European discourse. These reductionist readings of the colonial archive have been critiqued by Kim Wagner and Ricardo Roque, who persuasively argue for a "constructive attitude of critical engagement" with these archives in order to understand the nature of colonialism, remaining aware of the archives' limitations and exclusions, yet also appreciating their heterogeneous, complex nature and ambiguous meanings. In their view, "it makes little sense to dismiss colonial knowledge as being of inferior empirical value."14

How should historians read these sources in relation to studying colonial knowledge? Ann Laura Stoler has advocated using reading strategies such as reading along the grain, studying the ethnography of the archive, paying particular attention to the trajectories of specific documents in colonial archives to delineate the workings of colonial knowledge and governance. ${ }^{15}$ Conversely, reading against the grain of these documents can attempt to recover the words and agency of indigenous people. This chapter employs both strategies, alongside fully acknowledging the role played by indigenous agents in supplying and translating information for their European employers or producing accounts themselves. ${ }^{16}$ Scholars have argued that such actors played an important role

\footnotetext{
11 Ballantyne, "Colonial knowledge," 177-178.

12 Edward Said, Orientalism (London: Routledge \& Kegan Paul, 1978); Michel Foucault, Discipline and Punish: the birth of the prison (Harmondsworth: Penguin, 1979).

13 Gaytari Chakravorty Spivak, "Can the subaltern speak?", in Marxism and the interpretation of Culture, eds. Cary Nelson and Larry Grossberg (Chicago: University of Illinois Press, 1988), 271-313. Ballantyne, "Colonial knowledge," 180.

14 Kim Wagner and Ricardo Roque, "Introduction: Engaging Colonial Knowledge," in Engaging Colonial Knowledge: reading European archives in world history, eds. Kim Wagner and Ricardo Roque (Basingstoke: Palgrave Macmillan, 2012), 1-34, 1-6, 15 .

15 Ann Laura Stoler, Along the Archival Grain:Epistemic Anxieties and Colonial Common Sense (Princeton, N.J.: Princeton University Press, 2009); Wagner and Roque, "Introduction," 14, 18.

16 Wagner and Roque, "Introduction," 18, 23. An important study that examines indigenous
} 
in the construction and mediation of colonial knowledge, sometimes manipulating colonial perceptions to suit indigenous agendas. Consequently, colonial archives are "not simply synonymous with Western agency" and are a space for "countless fine negotiations, exchanges, entanglements and mutual accommodations." 17

Amidst the vast amounts of information gathered by the European powers that now reside in these archives, religion was a vitally important category of analysis for colonial authorities. ${ }^{18}$ In relation to Islam, European colonial and imperial officials produced an enormous amount of documents on the religious beliefs and practices of Muslims. These sources illustrate how notions of Islam influenced colonial and imperial policies and practices, such as the idea that Islam was an "organized religion that could be understood," the influence of travel accounts on colonial officials, and the role of Muslim intermediaries and informers in shaping European perceptions of Islam. ${ }^{19}$ In India, colonial authorities saw religion as a key lens for understanding sub-continental societies. ${ }^{20}$ Colonial conceptions of religious differences between Hindus and Muslims were central to British understandings of India's societal dynamics. British perceptions of Islam remained ambivalent and complex throughout this period, although a period of hostility after the Indian Rebellion of 1857 gave way to a more sympathetic approach by the late nineteenth century, albeit still laced with prejudice. David Motadel argues that studies of Islam and colonial knowledge "tend to underestimate the diversity of images of Islam" based on the methodological habit of not defining the source-base clearly, considering together official sources produced by those working for and within the colonial or imperial state alongside sources produced from outside these structures, such as literature, art, journalistic articles, pamphlets, and travel writings. These types of sources need to be separated out more carefully, to bring out this material's multiple purposes and audiences. ${ }^{21}$

Studies of the production and reception of colonial knowledge and Islam tend to be geographically bounded to a particular colony or territory, despite the efflorescence of scholarship on transnational history, focusing on the move-

agents in this knowledge-formation process is C.A. Bayly, Empire and information (Cambridge: Cambridge University Press, 1996).

17 Wagner and Roque, "Introduction," 24-25.

18 See for example Peter Gottschalk, Religion, Science and Empire: Classifying Hinduism and Islam in British India (Oxford: Oxford University Press, 2012).

19 Motadel, "Islam and Empires," 851-853.

20 Ballantyne, "Colonial knowledge," 190-192.

21 Motadel, "Islam and Empires," 855-856. 
ments of peoples, goods and ideas across national and colonial borders. ${ }^{22}$ The Hajj is a prime example of this type of movement, yet does not conform to a traditional site of European colonial knowledge production in the historiography. Nevertheless, studying transnational actors such as pilgrims can contribute to rich historiographies that are focused on particular territories. Every year, tens of thousands of European colonial subjects left areas under European rule or influence to travel to the Hijāz, an imperial space under Ottoman rule, to perform the Hajj, and European consulates in Jeddah produced thousands of pages of documentation recording this phenomenon. Although the European representatives in Jeddah were consular rather than colonial, we can justifiably call this material 'colonial knowledge' given that part of its focus is on colonial subjects and what affected these subjects during their pilgrimages.

In Sugata Bose's Hundred Horizons, he explains that "the colonial perception of the pilgrimage as ordeal and the pilgrim as victim gives a very partial, loaded and distorted picture of the journey to Mecca. Yet that perception needs to be analysed, because it impinged directly on the conduct of the pilgrimage."23 Bose examines the 1926 pilgrimage report of the British consulate at Jeddah as a "perfect example of the colonial view of the Hajj," focusing on the British Consul's perception of the Hajj and pilgrims. ${ }^{24}$ This chapter extends Bose's analysis by focusing in detail on the selection, production, and presentation of information regarding the Hajj in the consulate's pilgrimage reports over roughly half a century. While acknowledging that the official sources dwell on the pilgrimage's material difficulties and are "indispensable to reconstructing the broad lineaments of the annual Hajj," Bose perhaps unfairly criticises them for conveying "little of the spiritual fervor of the individual pilgrim or, indeed, of the collective experience of the faithful" nor providing any sense of the spiritual experience that transcended pilgrims' trials and tribulations. ${ }^{25}$ The Hajj reports were never intended to perform such roles, being collated and written with the instrumentalist objective of providing information on the

22 For example, George Trumbull, An empire of facts: colonial power, cultural knowledge and Islam in Algeria, 1870-1914 (Cambridge: Cambridge University Press, 2009). Two succinct overviews of transnational history are Akira Iriye, Global and Transnational History: the past, present and future (Basingstoke: Palgrave Macmillan, 2013) and Pierre-Yves Saurnier, Transnational History (Basingstoke: Palgrave Macmillan, 2013).

23 Sugata Bose, A Hundred Horizons: the Indian Ocean in the age of global empire (Cambridge, MA: Harvard University Press, 2006), 206-207.

24 Bose, Hundred Horizons, 209-211.

25 Bose, Hundred Horizons, 207, 220. 
Hajj to those in British officialdom who had dealings with the pilgrimage. As a source for analysing British knowledge of the Hajj, however, they remain invaluable.

As to the purposes of this knowledge, Eric Tagliacozzo has argued that the accumulation of information on pilgrim-subjects by European consulates in Jeddah was designed to exercise supervision over colonial subjects. In his view, there was a "huge and ever expanding apparatus of colonial control" in place by the interwar period, with European consulates in Jeddah engaged in colonial espionage in the Hijāz, serving as hubs of a "vast system of espionage and control over pilgrims by Western power." 6 The Hajj was viewed as a "feared transmission vehicle of militancy and subversion," and control over the pilgrimage was seen as "fundamental to ensuring the bedrock of European rule."27 This speaks to a wider debate among scholars who have emphasised the power of colonial knowledge as enabling colonial conquest and sustaining colonial rule and control. ${ }^{28}$ Bernard Cohn argued in his influential work that the administrative processes of the colonial state in India were designed to control local societies, and state practices were based on the production and ordering of this knowledge. ${ }^{29}$ However, in relation to the Hajj and Britain, colonial knowledge was often imperfect and partial, and there were real limits to the reach and effectiveness of colonial surveillance and supervision of pilgrims, especially once pilgrims disembarked from their ships onto the soil of the Hijāz. Many parts of the pilgrimage remained firmly beyond the reach of the informationgathering apparatus of the British consular authorities, whether they were British or Muslim.

\section{The Hajj Reports of the British Consulate at Jeddah}

From the 1860 , Arabia was a space of increasing interest to Britain. Information on the Hajj was believed to have a variety of practical applications, which included signalling the presence of epidemic disease in Arabia to imperial authorities, monitoring pilgrims who might pose a threat to British imperial interests, and highlighting instances of British pilgrims' mistreatment in the

\footnotetext{
26 Tagliacozzo, Longest Journey, 177-178, 299-300.

27 Tagliacozzo, Longest Journey, 178-180.

28 Spivak, "Subaltern" and Nicholas B. Dirks, "Foreword," in Bernard Cohn, Colonialism and its forms of knowledge: the British in India (Princeton, N.J.: Princeton University Press, 1996), ix-xviii.

29 Cohn, Colonialism.
} 
Hijāz, which could be taken up with the local authorities in Arabia as one method of exercising British influence in the area. Britain's ability to gather information on their pilgrim-subjects differed from place to place; this task was easier when pilgrims were on board ships to and from the Hijāz, given their enclosed nature. ${ }^{30}$ Indeed, reducing pilgrims to numbers and presenting the Hajj in numerical terms formed a substantial part of the Hajj reports. From the first very brief Hajj report in 1869 , the volume of information collected by British consular authorities expanded from 1878 with the appointment of Dr. Abdur Razzack on Hajj-related duties. The conditions of the First World War meant the priorities of British information-gathering shifted, reflected in reports by Muslim officials. After the war, the Jeddah consulate's Hajj reports became ever-more voluminous, covering a very wide variety of topics on the Hajj, with the Indian Vice-Consul, Munshi Ihsanullah, taking a particular concern with the various difficulties British pilgrims faced while in the Hijāz. As Eric Tagliacozzo has pointed out, this information-gathering formed part of a broader trend that sought to supervise colonial subjects through legal and coercive means. However, attempts at supervising and regulating some pilgrims, such as so-called "pauper" pilgrims from India, were limited. The Hajj reports were one component of a broader British effort to "know Islam" and contained various negative representations of pilgrims, which formed part of a broader discourse around the religion. ${ }^{31}$ The contributions of Britain's Muslim employees to these Hajj reports played an important role in shaping these discourses and furthering these broader aims.

Britons' engagement with the Hijāz began in the seventeenth century, with a small number of merchants based in the Hijāz's port city of Jeddah. Napoleon's 1798 invasion of Egypt led to naval actions by British forces in the Red Sea in 1799-1800, and relations were opened with the Sharif of Mecca. ${ }^{32}$ The foundation of official British representation in the Hijāz was the establishment of British Agents in Jeddah, Suez, and Qusayr in October 1837, upgraded to ViceConsuls by the Foreign Office one year later. ${ }^{33}$ The British consulate at Jeddah was the base for official information-gathering efforts regarding the Hajj, which were catalysed by two factors, disease and the opening of the Suez Canal in 1869 .

3o Tagliacozzo, Longest Journey, 191.

31 Tagliacozzo, Longest Journey, 194-195.

32 M. Abir, "The 'Arab Rebellion' of Amir Ghalib of Mecca (1788-1813)," Middle Eastern Studies 7.2 (1971): 185-200, 189-191.

33 William Roff, "Sanitation and Security: The Imperial Powers and the Nineteenth Century Hajj," Arabian Studies vi (1982): 143-161, 145. 
In 1865, a cholera epidemic killed thousands of pilgrims and reached Europe; over 200,00o people died worldwide. This epidemiological threat to Europeans focused governments' attention on the Hajj as a vector for disease transmission. Alongside the establishment of quarantine camps and procedures related to pilgrims' movements in the Red Sea region and in European colonies, Europeans felt an urgent need to monitor and collect information on sanitary and public health conditions in the Hijāz. ${ }^{34}$ In the British case, this was less marked - it was only until after the First World War that detailed reports on diseases in Mecca and Medina were compiled. ${ }^{35}$ The Suez Canal's importance as a strategic maritime artery for Britain's imperial interests meant the Red Sea became a space as equally vital as the Canal, which became contested through the rivalry between European powers and the Ottoman Empire. Consequently, conditions on the littorals and hinterlands of the Red Sea received greater attention than before. The Hajj was arguably the largest annual event that took place in this area, its religious significance drawing Muslims from across the world to Mecca every year, many of whom were subjects of the European empires. The Canal's opening created multiple new shipping routes in the Red Sea and Indian Ocean, increasingly plied by steamships in everincreasing numbers. ${ }^{36}$ Mainly European shipping companies established many routes for the pilgrim trade, and travel firms such as Thomas Cook entered the market, detailed in Michael Christopher Low's chapter in this volume. Combined with the use of steamships, the cost of a ticket to the Hijāz became much more affordable to a greater number of pilgrims than before. Pilgrim numbers mushroomed from approximately 100,000 in the 1830 s to around 300,000 in the 189 os. $^{37}$ This steady increase in the number of seaborne pilgrims and the epidemic diseases they carried marked them out for increased scrutiny from colonial and consular officials.

The systematic collection of information on the Hajj by the British consulate in Jeddah began in $1869 .{ }^{38}$ These pilgrimage reports contained little

34 Peters, Hajj, 301-315.

35 Tagliacozzo, Longest Journey, 149. The relationship between epidemic diseases, the Hajj and European imperialism has been extensively analysed in Roff, "Sanitation and Security"; Tagliacozzo, Longest Journey, 133-156; M.C. Low, "Empire and the Hajj: Pilgrims, Plagues and Pan-Islam, 1865-1908," International Journal of Middle Eastern Studies 40 (2008): 269-290, and Saurabh Mishra, Pilgrimage, politics and pestilence: the Haj from the Indian Sub-continent, 1860-1920 (Delhi: Oxford University Press, 2011).

36 Michael Miller, "Pilgrim's Progress: The Business of the Hajj," Past and Present 191 (2006): 189-228.

37 Roff, "Sanitation and Security," 143.

38 Not in 1882, as Eric Tagliacozzo points out in Longest Journey, 179. 
material compared to those compiled in the 1920 and 1930s, which ran to over thirty pages. In 1869, for example, Arthur Raby, the Consul in Jeddah, merely wrote that after the pilgrimage, the Hijāz's public health was satisfactory; about 110,00o pilgrims stood at Mount 'Arafāt, and 5,000-6,000 pilgrims waited for ships in Jeddah after the Hajj's conclusion. ${ }^{39}$ The quantity of information did not greatly increase the year after, except for the observation that 1870 was marked by a "Grand Pilgrimage," Hajj Akbar, a one in seven year event, when performing the Hajj carried greater spiritual benefit to pilgrims. ${ }^{40}$ British officials in Jeddah and India came to realise that Britain needed to employ Muslims in order to expand the scope of their nascent knowledge of the pilgrimage.

Consequently, Assistant Surgeon Dr. Abdur Razzack of the Bengal Medical Service was sent by the government of India to perform the Hajj in 1878 , in order to monitor the sanitary situation of Indian pilgrims and assess the effects of the quarantine lazaret at al-Ṭur in the Red Sea, opened in $1877^{41}$ The Indian government sent Razzack on Hajj annually from 1878-1882, and his reports were read by officials in London, Aden, Egypt, India, and Malaya. His employment in the Jeddah consulate was formalised in 1882 and he became permanently based there. Significantly, Razzack's remit was expanded from reporting on sanitary matters to include providing assistance to Indian pilgrims and concerning himself with their general welfare while in the Hijāz..$^{42}$ As Ulrike Freitag has argued, despite the position of European Consuls as representatives of imperial powers, in Jeddah they were "helpless," their position "heavily circumscribed" due to their enforced isolation from local society. Consequently, employing Muslims enabled these difficulties to be partly overcome. As a Muslim, Razzack could travel to Mecca to collect information on the Hajj, unlike his Christian British employers, although local Ottoman officials were unhappy with an official representative of Britain going to Mecca. Razzack also forged good relations with Hijāzis and Indians alike. ${ }^{43}$ The Vice-Consul's status gave him a privileged position in which to present his interpretations of the pilgrimage to his employ-

Report on the conclusion of the Hajj, March 29, 1869, FO 195/956, The National Archives, London (hereafter TNA).

40 Report on the conclusion of the Hajj, March 18, 1870, FO 195/956, TNA.

41 Medico-Sanitary Report on the Pilgrimage to Mecca by Dr. Abdur Razzack, Indian Medical Service, Appendix L, 99-103, in Memorandum by Mr. Netten Radcliffe on Quarantine in the Red Sea, and on the Sanitary Regulation of the Pilgrimage to Mecca, June 1879, 52, PC $1 / 2674$, TNA.

42 Roff, "Sanitation and Security," 147-148; Low, "Empire and the Hajj," 283.

43 Freitag, "Helpless Representatives," 359, 362, 365, 374-375. 
ers, who in the case of the Consul were often posted to Jeddah for only a short period of time, increasing their reliance on Muslim subordinates such as Razzack.

Two examples of Razzack's perspectives on and representations of the pilgrimage concern the Hajj and Muslim unity and destitute Indian pilgrims. Razzack argued to his employers that in some cases the Hajj did not facilitate a feeling of Muslim unity among the umma. The doctor was anxious that the "timid and ignorant peasantry of East Bengal," who generally made up half the numbers of Indian pilgrims, were "under the thumb of their spiritual guides [mutawwifin, pilgrim guides] not only from natural pliability, faith and credulity, but their almost complete inability to communicate with the people of this country." ${ }^{\prime 4}$ Razzack's derogatory remarks can be taken as representative of British officialdom's view of most Indian pilgrims in this period, as a poor, helpless, credulous mass of pious people. Yet his comments underscore a vital point that complicates views of the pilgrimage's unifying effect on Muslims. Most pilgrims were not multi-lingual. They were reliant on the proficiency of their mutawwif in Arabic to negotiate the Hajj experience. Successive Hajj reports represented pilgrim guides as parasitic on pilgrims, and Britain's Muslim Vice-Consuls often presented this viewpoint most forcefully.

Razzack's pilgrimage reports were also instrumental in shaping official views of destitute Indian pilgrims, a group who were an important concern of British authorities involved with the pilgrimage throughout this period. ${ }^{45}$ In 1886 , he wrote that their living conditions in the Hijāz were "miserable ... heart-rending to behold." However, Razzack thought their religiosity "will busy up the hearts of even the poorest and most destitute and steel them to bear every variety of privation and misery in the hope of a better future thereafter." ${ }^{\prime 6}$ Razzack's passages on destitute pilgrims in his Hajj reports were written with the purpose of improving this group's pilgrimage experience. His 1887 Hajj report opened with an emotive passage on the issue; indigent pilgrims stranded in Jeddah suffered from "want, privation and disease." That year's pilgrimage had the highest number of destitute pilgrims on record: over 4,955 from India out of 10,324 in total, nearly $50 \%$. The Ottoman authorities complained to Britain about this large influx of indigent pilgrims. While Indian Muslim merchants in Jeddah assisted with destitute pilgrim repatriation, Razzack felt that a fund for these indigent pilgrims was urgently needed, although he reflected Victorian

\footnotetext{
44 Dr. Abdur Razzack, Report on the ${ }_{1885}$ Hajj, February 27, 1886, Fo 78/4094, TNA in RoH, 3, 675 .

45 Low, "Empire and the Hajj," 274.

46 Dr. Abdur Razzack, Report on the 1886 Hajj, undated, FO 195/1583, TNA in RoH, 3, 747-748.
} 
conceptions towards the poor in arguing that only the "absolutely helpless" should be assisted. ${ }^{47}$ Razzack's advocacy came to fruition with greater official support for repatriation at the end of the nineteenth century.

Dr. Razzack's murder by Bedouins outside Jeddah on 30 May 1895 highlighted how differing conceptions of knowledge proved fatal for the doctor. The Bedouin thought Razzack and the British Consul who was walking with him were quarantine doctors, whom they despised; a hospital and disinfecting machine had recently been attacked in Mecca, because the Bedouin thought these things and the doctors were responsible for cholera. ${ }^{48}$ The doctor's successor as Vice-Consul, Dr. Mohammed Hussein, also played an important part in shaping British knowledge of the Hajj. In his 1896-1897 Hajj report, he began with a detailed account of the pilgrimage's origins in the sixth and seventh centuries C.E. Building on this knowledge, Hussein wrote that according to the Qurann, performing the Hajj was only compulsory for those who could afford it, as a precursor to castigating the "blind religious zeal of millions of uneducated Moslems" who were encouraged by pilgrim guides who travelled across India to attract pilgrims to Mecca. The work of these guides, coupled with unrestricted travel and improvements in transportation, made pilgrims view the Hajj as "the only source of salvation open to them." Hussein attributed these factors to the Hajj attaining "such magnitude that it has attracted the attention of all the leading powers of the world."49 Razzack and Hussein played a vital intermediary role in expanding Britain's knowledge of the Hajj, shaping the way in which this knowledge was represented and interpreted to British officials, a trend continued by their successors in the interwar period.

Despite the employment of Muslims in Britain's Jeddah consulate, Britain's ability to mount surveillance over so-called 'Islamic conspiracies' among pilgrims remained limited, because such goings-on appeared rather nebulous, compounded by the difficulties of obtaining accurate information on them. A good example of this was official concerns that funds were being raised in India by pilgrims for a jihad in the name of Mecca and Medina during the $1870 \mathrm{~s}-$ it turned out the fundraising was actually for a project to improve the water sup-

47 Dr. Abdur Razzack, Report on the 1887 Hajj, February 15, 1888, FO 195/1610, TNA in RoH, 3, $761,783-785$.

48 W.S. Richards, Consul Jeddah, to Secretary, Foreign Department, Government of India, June 23, 1895, Foreign Department, Secret—E, September 1895, No. 44-64, National Archives of India, New Delhi (hereafter NAI).

49 Jeddah Vice-Consul Dr. Mohamed Hussein, Report on the Mecca Pilgrimage 1896-1897, 1-2, Foreign Department, External—A, March 1898, No. 206-215, NAI. 
ply to the Holy Cities. ${ }^{50}$ Official viewpoints towards 'Islamic conspiracies' and the Hajj were diverse. Some saw the Hajj as a hotbed of conspiracies, while others were sceptical about the extent of the pilgrimage's role as a catalyst for anti-colonial movements and Islamic radicalism. ${ }^{51}$ British pilgrimage reports in this period hardly cover such activity.

However, some British Consuls in Jeddah, such as J.N. Zohrab, struck a more alarmist note. In 1879, Zohrab reported that various Muslim nationalities in Mecca were now in close correspondence with each other: "the organization seems complete and the union perfect, and restless spirits are ever moving in search of pretexts to raise complications." ${ }^{2}$ Zohrab believed that the Hijāz was a key fulcrum around which this nebulous organization was based because of the Hajj. ${ }^{53}$ In relation to pilgrims who were British subjects, Zohrab thought some went on Hajj for political purposes, because Mecca was "free from European intrusion" and a safe area for meetings "at which combinations hostile to us may form without our knowing anything till the shell bursts in our medst [sic]." The Consul argued for Muslim secret agents to monitor the Hajj at Mecca to forestall any "hostile combinations," a proposal rejected by his superiors as impractical. ${ }^{54}$ This type of imperial alarm regarding the Hijāz and the Hajj extended to Dutch officials, who had greater cause for concern, given their on-going war against the Muslim Sultanate of Aceh, and the community of Acehnese and other Dutch colonial subjects who lived in the Hijāz. ${ }^{55}$

The dramatic tone of Zohrab's reports, however, should not be taken as representative of a monolithic imperial viewpoint towards the Hajj. Of course, one of Zohrab's roles was to ascertain any threats to British interests which emanated from the Hijāz, but his lack of concrete details on such threats shows the uncertainty of the information at his disposal. These reports need to be read

50 Azmi Özcan, Pan-Islamism: Indian Muslims, the Ottomans and Britain 1877-1924 (Leiden: Brill, 1997), 93.

51 Seema Alavi, "'Fugitive Mullahs and Outlawed Fanatics': Indian Muslims in NineteenthCentury Trans-Asiatic Imperial Rivalries," Modern Asian Studies 45.6 (2011): 1337-1382, 1381-1382.

$5^{2}$ Zohrab, Consul Jeddah, to Marquis of Salisbury, March 12, 1879, HD 3/55, TNA.

53 Zohrab, Consul Jeddah, to Marquis of Salisbury, January 9, 1880, HD 3/55, TNA.

54 Zohrab, Report on the Necessity of a Consular Establishment in the Red Sea, June 1, 1881, FO 195/1375, TNA, quoted in Saleh Muhammad al-Amr, The Hijaz under Ottoman Rule, 1869-1914 (Riyadh: Riyad University Publications, 1978), 171. Under Secretary State for India to Under Secretary State for Foreign Affairs, January 28, 1881, Foreign Department, Secret, March 1881, No. 156-160, NAI. Also quoted in Roff, "Sanitation and Security."

55 Fred Von Der Mehden, Two Worlds of Islam: Interaction between Southeast Asia and the Middle East (Gainesville, FL: University Press of Florida, 1993), 3-8. 
against his realisation that Britain's ability to acquire further information on the pilgrimage remained limited without further recourse to Muslim employees. By the interwar period, Hajj reports routinely noted the presence of "political agitators" from India without further elaboration, and also mention that some were on "excellent terms" with the Indian Vice-Consul, perhaps indicating how the British no longer saw the Hajj as an unknown space for anti-colonial conspiratorial activity. ${ }^{56}$

In contrast to 'Islamic plots', Britain's Hajj reports devoted significant attention to recording the numbers of pilgrims arriving and departing from the Hijāz and their origins, in order to grasp the scale of this phenomenon, and form a basis for closer supervision of British pilgrim-subjects. When considering these pilgrim numbers, Michael Laffan's cautionary note is salutary: "the statistics are more an indication than a hard fact." ${ }^{57}$ For example, in 1926, the Saudi Minister for Foreign Affairs stated the total number of pilgrims was 120,000, but other eye-witnesses reported to the British Consulate's staff that there were no more than $100,000 .^{58}$ British reports disparaged Saudi estimates, one arguing they were "ascribed as much to ignorance as to ecstasy. The desert so seldom teems that the Arab has but little knowledge of large numbers." ${ }^{59}$ One numerical feature that concerned the consular authorities was a continued mismatch between the number of arriving and departing pilgrims in the Hijāz, attributed to a high death rate and an observation that many pilgrims seemed elderly. Officials believed that once old pilgrims had performed the Hajj "the force of fanaticism which had so long sustained them peters out, and the desire to go on living deserts them. They die in consequence, and are glad of the release." 60 This understanding reflected a broader perception of pilgrims as almost fatalistic.

While the Hajj reports contain numerous tables recording numbers of incoming and outgoing pilgrim ships in Jeddah, these numbers, and data on pilgrims' origins, were frequently inaccurate. In 1884, Razzack found "a difference in every [ship's] case."61 Consular authorities wanted to ascertain pilgrims' origins in order to discover exactly who deserved consular assistance.

$5^{6}$ Report on the Hajj of 1350 A.H. (1932), FO 371/16018, TNA, RoH, 6, 492.

57 Michael Francis Laffan, Islamic nationhood and colonial Indonesia: the umma below the winds (New York: Routledge Curzon, 2003), 53.

$5^{8}$ Report on the Hajj of 1344A.H. (1926), FO 371/11436, TNA, RoH, 6, 42.

59 Report on the Hajj of 1350 A.H. (1932), FO 371/16024, TNA, RoH, 6, 483.

6o Report on the Hajj of 1344A.H. (1926), FO 371/11436, TNA, RoH, 6, 55 .

61 Dr. Abdur Razzack, Report on the Pilgrimage Season of 1301A.H. (1884), Fo 891/5113, TNA, $\mathrm{RoH}, 3,587$. 
This information was especially important regarding Indian "pauper" pilgrims, recorded as a distinct category by Razzack. In response to Ottoman pressure regarding large numbers of poor pilgrims stranded in Jeddah, Razzack observed the wharf at Jeddah where pilgrims congregated, and concluded that a third of these "Indian pauper pilgrims" were from Afghanistan, Baluchistan, Central Asia and Xinjiang. ${ }^{62}$ Categories in the reports' tables were frequently capacious, such as "Javanese and Malays" and "other Africans." ${ }^{63}$ By the 1920s, these tables had expanded in size and specificity, but remained indicative at best in some cases, such as "Various Far Eastern pilgrims (Chinese, Siamese, Philippine islanders \& c)." ${ }^{64}$ Officials blamed quarantine authorities in non-British territories for classifying pilgrims by race rather than nationality. ${ }^{65}$ In the 1930 , with the wider introduction of passes and passports, the British consulate could tabulate the province or princely state Indian pilgrims had come from, but only for those pilgrims who had not lost their documentation. ${ }^{66}$ Records of pilgrim numbers and origins show the limits of British knowledge of the Hajj.

In 1914, with the closure of Britain's consulate in Jeddah as a result of the outbreak of war between Britain and the Ottoman empire, it seemed British knowledge of the Hajj would lose its base in the Hijāz for the foreseeable future. Before leaving, Vice-Consul Dr. Abdur Rahman wrote in his last Hajj report that he had reported on six successive pilgrimages and trusted that he "succeeded in bringing before the authorities and the Indian public all the hardships the pilgrims had to face in the performance of this, their great religious duty, partly through their own ignorance and partly through circumstances beyond their control." ${ }^{67}$ Rahman was aware that his reports were "not very palatable" to some Indian Muslims, but stressed it was not disrespectful towards the Holy Cities to criticize various aspects of the Ottoman Hajj administration: "all I wished for was improvement in the condition of affairs prevailing there, bettering the treatment of pilgrims during their sojourn in the Holy Places and sure means of their return home." ${ }^{68}$ He believed his reports' recommendations "had a very favourable echo from proper quarters," such as the establishment of Hajj

62 Dr. Abdur Razzack, Report on the Hajj of 1304A.H. (1887), FO 195/1610, TNA, RoH, 3, 766; Dr. Abdur Razzack, Report on the Hajj of 1303A.H. (1886), FO 195/1583, TNA, RoH, 3, 747.

63 Report on the Hajj of 1333A.H. (1915), IOR/L/Ps/10/523, India Office Records, Asia, Pacific and Africa Collections, British Library, London (hereafter IOR, APAC, BL).

64 Report on the Hajj of 1346A.H. (1928), FO 371/12999, TNA, RoH, 6, 188.

65 Report on the Hajj 1348A.H. (1930), FO 371/15290, TNA, RoH, 6, 259.

66 Report on the Hajj of 1346 A.H. (1928), FO 371/12999, TNA, RoH, 6, 196, 231.

67 Report on the Hajj of 1333A.H. (1915), IOR/L/Ps/10/523, IOR, APAC, BL.

68 Ibid. 
committees across India, which was his idea. ${ }^{69}$ Rahman's statements underline how British conceptions of the pilgrimage as a great hardship were shaped by Muslim voices in the official record such as his, and how these reports enabled Muslim officials to exercise some influence over British policy towards the Hajj.

In the febrile atmosphere of wartime, when Sharif Hussein's Arab Revolt was only a few months old, Cairo's Arab Bureau, which played an instrumental role in fomenting the Revolt, showed great concern in presenting Hussein's administration of the pilgrimage as a great success. The pilgrimage had been "most successfully performed. No untoward incidents, such as have been too frequent in former years, disturbed its course." Pilgrims "expressed their deep gratitude" in response to British efforts such as the requisitioning of two Khedival Mail Line ships from war duties to transport pilgrims. Familiar tropes were deployed to further the report's positive lines; "fanaticism" in Jeddah was "conspicuous by its absence" and Bedouins were "conspicuously friendly" on roads used by pilgrims. ${ }^{70}$ This positive interpretation of the Hajj under Hashemite rule was particularly important, as the reports were sent to various parts of British officialdom that were more ambivalent towards the Revolt, such as the Government of India. ${ }^{71}$ After the war ended, and conditions on the pilgrimage deteriorated as Hussein's subsidies from Britain decreased, British Hajj reports still tried to praise his pilgrimage administration. One in 1919 noted that "had the pilgrimage stopped at Mecca, all would have been well" before detailing Bedouin attacks on pilgrim caravans to Medina, prompted by the withholding of Hashemite funds to the Bedouin that had previously been generously dispersed. ${ }^{72}$

The pilgrimage during the Arab Revolt was seen as particularly important to various parts of Britain's Muslim empire whose subjects took a keen interest towards events in Mecca and Medina. A short report on the Hajj by a Muslim official, Mr. J.S. Kadri, was sent by the Political Resident at Aden to the High Commission in Cairo, the Governor-General of Sudan, the Pilgrimage Officer in Jeddah, the Government of Bombay and the Foreign and Political Department of the Government of India. Some of Kadri's perspectives on the pilgrimage could not be replicated by his British employers, for example his opening statement that "the ways of God are inscrutable and He does what men can never

\footnotetext{
69 Ibid.

$70 \quad$ Arab Bulletin, No. 26, 1 November 1916, RoH, 5, 57.

71 Briton Cooper Busch, Britain, India and the Arabs, 1914-1921 (Berkeley, CA: University of California Press, 1971).

72 Lt. Col. Vickery, British Agent, Jeddah, Extracts from a report on the Pilgrimage 1919, FO 371/4195, TNA, RoH, 5, 159 .
} 
divine. Hussein's overthrow of the Ottomans made it possible for Indians to go to Mecca and perform their most cherished and fundamental duties of the faith." Yet Kadri's observations of Jeddah were very similar to British officials stationed there after the outbreak of the Arab Revolt; the town was "nasty and filthy," and sanitary arrangements were "far from satisfactory." Mecca was seen as "more healthy" but the valley of Mina had "dirt and filth ... everywhere," and the lack of disease was attributed to good weather. Pilgrim guides "often try to fleece poor pilgrims of their money" and pilgrims on one ship were "openly bullied, insulted and even thrashed" by the ship's purser. ${ }^{73}$ Kadri's representations of the Hijāz's public health, pilgrim guides, and conditions on pilgrim ships are little different from Razzack's reports in the 188os. These negative conceptions of the Hijāz were furthered by Hakim Said Hassan, a policeman from India's United Provinces deputed to Britain's Hajj administration in Jeddah. Hassan wrote that "the moral character of the people is really disgusting ... it is not an uncommon sight to see men lying about dead drunk in Jeddah. Even in the holy city of Mecca people do not refrain from indulging in toxicants."74

The priority of emphasising pilgrims' support for British policies and actions in the Hijāz show how wartime exigencies shaped Kadri's Hajj report. The Government of India had provided three steamships from Bombay to Jeddah for 2,500 Indian pilgrims, and Kadri reported "a universal sense of heartfelt satisfaction and gratitude" among Indian pilgrims for the attention paid to their welfare by Colonel Wilson, Britain's Agent in Jeddah. The pilgrimage "passed off smoothly and happily" and pilgrims on the plain of Arafat "presented a unique sight, almost superhuman and sublime."75 Kadri concluded by reinforcing official conceptions of pilgrims as "generally illiterate and unacquainted with Arabic and the conditions of Arabia" which left them vulnerable to the unscrupulous practices of some pilgrim guides. Kadri argued for Britain to appoint a Protector of Pilgrims in Jeddah and Mecca, fluent in Arabic, Hindi and Bengali, attached to the British consulate at Jeddah. These recommendations were a standard formula for Britain's Hajj reports authored by Muslim officials, which recorded the various difficulties pilgrims faced before advocating further extensions of Britain's administrative engagement with the pilgrimage. ${ }^{76}$

Another aspect of Britain's knowledge of the Hajj particular to this wartime period was a concern to monitor French activities in the region, as Britain

Mr. J.S. Kadri, Educational Inspector, deputed from Aden, Note on his Experiences of the Haj 1916, Foreign and Political Department, War-Secret, March 1917, No. 67-69, NAI.

75 Mr. J.S. Kadri, A Pilgrim's Experiences, Arab Bulletin, No. 34, December 11, 1916.

76 Ibid. 
wished to remain King Hussein's chief ally. During the 1918 Hajj it was carefully reported that Sayyid Muhammad ibn Sasi, France's new representative in Mecca, brought King Hussein presents including silk carpets, gold watches, diamond pins, gold-chains and pistols, inscribed "from the French nation in memory of the Pilgrimage of ${ }_{133} 6 . "{ }^{\prime 77}$ While French influence in the Hijāz waned after the war's conclusion, the conquest of the Hijāz—and the Hajj—by Abd al-Aziz al-Saud of Najd in 1924 caused the information-gathering priorities of the British consulate, and the interpretation of this material, to change once more.

A major contributor to British knowledge of the Hajj through the British consulate's pilgrimage reports during the initial years of Saudi control over the Hijāz was Munshi Ihsanullah. Born in Punjab, India, Ihsanullah had been a merchant in Medina. Ruined by the war, he worked for British military intelligence in Damascus in 1918, then was employed at the British consulate in Jeddah. With knowledge of Urdu, Arabic and English, he was well-connected to officials, merchants, and pilgrim guides in the Hijāz, and with Indian pilgrims. He was appointed as Indian Pilgrimage Officer in 1925 and promoted to Indian Vice-Consul in 1927. Successive British Consuls lauded Ihsanullah; one wrote that his "unflagging energy, his loyalty and genuine devotion to the cause of the pilgrimage are deserving of the highest praise." The 1928 Hajj report revealed how Ihsanullah gathered some of his information, describing how his living quarters in Jeddah were turned into a "free club" for Indian pilgrims"he gleans in this way much information of a valuable nature."78 Ihsanullah supplied much material for Britain's Hajj reports, and the 1931 report was attributed to him. The British Consul, C.G. Hope-Gill, thought Ihsanullah had become "something of an expert in all pilgrimage matters." Hope-Gill also shed light on how Ihsanullah produced the Hajj reports. Ihsanullah's writings in Urdu were translated into English by his clerks Shah Jahan Kabir, Sayyid Nur Hussein Shah and Haji Mohammed Sharif. ${ }^{79}$ Andrew Ryan, British Consul in 1932, stated at the outset of that year's report that although he "edited the material freely the enclosed report is almost entirely based on what has been supplied by members of staff," mainly Ihsanullah. ${ }^{80}$ The Indian ViceConsul's work was circulated widely among British authorities who had some connection to the imperial administration of the Hajj; the 1932 report, for example, was copied to the Foreign, India and Colonial Offices in London,

\footnotetext{
77 The Pilgrimage, 1918, Arab Bulletin, No. 107, 6 December 1918, RoH, 5, 117.

78 Report on the Hajj of 1346 A.H. (1928), FO 371/12999, TNA, RoH, 6, 204.

79 Report on the Hajj of 1349A.H. (1931), FO 371/15291, TNA, RoH, 6, 396.

801932 Pilgrimage Report, 1, IOR/R/20/A/3524, IOR, APAC, BL.
} 
and British administrations in Palestine, Iraq, Nigeria, Malaya, India, Egypt, and Sudan. ${ }^{81}$

By the mid-1920s, the Hajj reports covered a wide variety of topics at some length, the 1932 report being a representative example at nearly fifty pages long. The reports' sections included pilgrim numbers, quarantine in the Red Sea and the Hijāz, pilgrims' lost luggage, public security, public health, estates of British subjects who died in the Hijâz, intimidation of pilgrims by the authorities, religious intolerance, pilgrim shipping and ports of origin, the Indian pilgrimage with sub-sections on staff and destitute pilgrims, pilgrim registration at Jeddah, loans to pilgrims, the Egyptian pilgrimage with sub-sections on pilgrim dues, shipping, the mahmal, destitute pilgrims, Egyptian restrictions against returning pilgrims, and a final sub-section on pilgrims from other territories within and outside the British empire, such as Malaya, Sudan and West Africa, Aden, the Levant, Hadramaut, Somaliland, Najd and Yemen. This report and others from this period also presented financial information, calculating how much the pilgrimage cost for British colonial subjects across Britain's Muslim empire, recording figures on tariffs levied on pilgrims in Arabia, the cost of camel hire, and shipping costs. ${ }^{82}$

Ihsanullah's input and perspectives clearly shaped the manner in which certain aspects of the Hajj were presented to British officials and understood by them. When the Saudis conquered the Hijāz in 1924, they sought to impose their interpretation of Islam on the local population. The Hajj reports contained a new sub-section detailing the "religious restrictions" imposed by the Saudis which affected pilgrims, such as being prevented from praying at certain tombs in the Hijāz. The reports chart the fluctuations in Saudi religious policy towards pilgrims, recording various incidents. In 1928, for example, two imams of mosques in Bombay reported to Ihsanullah that they were beaten by Najdi guards after praying in front of Prophet Muhammad's tomb with their hands raised..$^{83} \mathrm{~A}$ further example from the 1931 report written by Ihsanullah records the Saudi ban on head-dresses worn by a community of Patani Indian Muslims while performing the tawa $\bar{a}$, a policy that "clearly indicates the extent of Wahhabi bigotry and fanaticism." ${ }^{84}$ The effect of the Great Depression on the Hijāz, which led to a collapse in pilgrim numbers, contributed towards what Ihsanullah saw as "a marked tendency in the direction of a more liberal policy"

\footnotetext{
$81 \quad$ Ibid.

82 Ibid. Tagliacozzo, Longest Journey, 190.

83 Report on the Hajj of 1346, (1928), FO 371/12999, TNA, RoH, 6, 195.

84 Report on the Hajj of 1349A.H., (1931), FO 371/15291, TNA, RoH, 6, 379.
} 
by the Saudi authorities towards pilgrims' religious practices. ${ }^{85}$ Through these reports, Ihsanullah was an important actor who shaped conceptions of Saudi religious policies in the British 'official mind.'

An older feature of British Hajj reports were pilgrim guides, who had appeared in them since the 1880 s, with a consistent focus on the guides' ability to over-charge pilgrims for their services. The section on pilgrim guides in the 1930 report was "based on information supplied and views held" by Ihsanullah, and his experience with this group gave "great weight to his opinions." ${ }^{86}$ Ihsanullah's objective regarding these pilgrim guides was greater regulation over their activities to protect Indian pilgrims, evidenced by his numerous suggestions to regulate the guides' "mischief and malpractices." ${ }^{87}$ In liaison with colonial authorities in India, Ihsanullah established a 'black-list' of pilgrim guides known to defraud pilgrims, who were banned from visiting India to proselytise the merits of performing the Hajj. ${ }^{88}$ The power of Ihsanullah's 'black-list' was sufficient for it to be raised as a topic of concern by the Saudi Minister of Foreign Affairs with the British Consul. ${ }^{89}$ Ihsanullah's activism led to a backlash from the pilgrim guides, and once he retired in 1937, British perceptions of this group became more resigned and stereotypical of an unchanging Arabia; guides "have been oppressing pilgrims for more than 1,300 years and it is too much to hope they will stop. ${ }^{90}$ While Ihsanullah's perceptions of pilgrim guides as rapacious aided his efforts to regulate their activity through applying his knowledge of them to a 'black-list,' this initiative was short-lived, another example of the limits official British knowledge faced in changing the Hajj experience for British pilgrim-subjects. The Hajj reports produced by the British consulate in Jeddah illustrate the important role played by Muslim employees in the production of official knowledge about the Hajj and in shaping official understandings and interpretations of the ritual. The reports also demonstrate the limits of how this knowledge could be deployed in the pursuit of greater supervision over British pilgrim-subjects.

85 Report on the Hajj of 1351A.H., (1933), FO 371/16857, TNA, RoH, 6, 559.

86 Report on the Hajj of 1348 A.H., (1930), FO 371/15290, TNA, RoH, 6, 271.

87 Report on the Hajj of 1349A.H., (1931), FO 371/15291, TNA, RoH, 6, 379.

88 Report on the Hajj of 1353A.H., (1935), FO 371/19002, TNA, RoH, 7, 37.

89 Report on the Hajj of 1354A.H., (1936), FO 371/20055, TNA, RoH, 7, 121.

90 Report on the Hajj of 1356 A.H., (1938), R/15/1/576, IOR, APAC, BL, RoH, $7,290$. 


\section{The Protector of Pilgrims Reports on the Pilgrimage from Bombay}

The priorities of knowledge production surrounding the pilgrimage from Bombay were somewhat different to the British consulate in Jeddah, given the port city's status as a British colonial city. As the principal port for Indian pilgrims travelling to and from the Hijāz, Bombay saw thousands of pilgrims arrive in the city each year. As a representative example, 21,00o pilgrims passed through the city in 1909, out of which some 13,000 arrived over seventeen days. ${ }^{91}$ This movement of pious people was of little concern to the city's colonial authorities until the 188 os, when a series of scandals relating to conditions on pilgrim ships and other criticisms levelled at the lack of regulation around pilgrims in Bombay led the government to appoint the city's first Protector of Pilgrims in 1887. The Protector, a Muslim, headed a Pilgrim Department of administrative officials. Given the Protector's responsibility for administering the flow of pilgrims from Bombay, he and his department's "great pressure of work" was wide-ranging during the season when pilgrims arrived in Bombay. These duties included visiting every vessel that returned from Jeddah in order to liaise with ship's captains and doctors; receiving complaints from pilgrims; noting the Ottoman authorities' treatment of pilgrims; visiting hostels where destitute pilgrims lodged and arranging repatriation to their homes across India; attending local hospitals to enquire about sick pilgrims, answering enquiries from people who wanted news of lost relatives who had gone on Hajj, and responding to numerous queries from pilgrims about sailing dates, shipping companies, passage rates, hostels, vaccinations, expenses and provisions for the journey, passports, quarantine, and depositing cash. ${ }^{92}$

The expansive nature of the Protector's work and the administrative logic of the 'document Raj' meant that a report on the pilgrimage from Bombay was produced annually. ${ }^{93}$ Like the Hajj reports from Jeddah, the document received a wide circulation among India's colonial bureaucracy. By the interwar period, it was sent to the Commissioner in Sindh, Bombay's Commissioners of Police and Excise, Collector of Customs, Surgeon-General, Port Health Officer, Port Officer, Municipal Commissioner, the Political Resident in Aden, the Government of India's Political Department, the Director of Information, and the Sec-

91 Protector of Pilgrims, Report on Pilgrim Season ending November 30, 1909, April 9, 1910, General Department, 1910, Vol. 134, File 615, MSA.

92 Protector of Pilgrims, Report on Pilgrim Season 1910, May 10, 1911, General Department, 1911, Vol. 158, File 992, MSA.

93 The concept of a 'document Raj' is explored in Bhavani Raman, Document Raj: writing and scribes in early colonial south India (Chicago: The University of Chicago Press, 2012). 
retary of India's Legislative Council. In a significant difference from the Jeddah Hajj reports, the Protector's reports were also intended for public consumption, at least for the minute proportion of those in India who could read English, being sent to newspaper editors and all registered libraries, which undoubtedly influenced the content and tone of these documents. ${ }^{94}$

Examining two reports on the pilgrimage from Bombay in 1925 and 1932, both present an overall picture of an efficient administration attempting to deal with the annual influx of thousands of pilgrims to Bombay, who were buffeted by the broader political and economic forces that affected the pilgrimage. In 1925, the Protector of Pilgrims Abdulkarim Mirajkar complained that his department had to spend much time answering queries from pilgrims relating to conflicting reports given by pilgrim guides from the Hijāz who were in Bombay, who either supported Hashemite King Ali or Abd al-Aziz al-Saud, then at war with each other in the Hijāz. A further hindrance to the department's work in 1925 was the debate over whether the pilgrimage should be discouraged because of this wartime situation in the Hijāz. Mirajkar outlined the Government of India's communiqué in April 1925 which stated there would be no official obstacle to those who wanted to perform the Hajj and the government "would abstain studiously, as heretofore, from all interference." This was a key shibboleth of British policy, frequently repeated in documents related to the Hajj. Mirajkar's report stressed the positive role the colonial government played in facilitating the Hajj in wartime conditions for Indian pilgrims - the authorities "lost no time" in making arrangements for pilgrims to land in Rabegh, a port under al-Saud's control, and reminded al-Saud of his responsibility for the safety of British subjects. ${ }^{95}$ In 1932, due to the effects of the Great Depression, the main feature of the Hajj that year was a collapse in pilgrim numbers- "one of the poorest on record"-attributed by the Protector to the fact that most pilgrims were Bengali, whose province was particularly affected by unemployment, coupled with the Saudi policy of demanding pilgrim dues be paid in gold, which further discouraged pilgrims. ${ }^{96}$ The reports portray the Pilgrim Department benignly shepherding pilgrims towards their spiritual goal in the face of external forces beyond their control.

94 Report of the Protector of Pilgrims, Bombay for the Pilgrim Season, 1925, 18 December 1925, Foreign and Political Department, 393-N, 1926, NAI (hereafter 1925 Report); Report of the Protector of Pilgrims, Bombay for the Pilgrim Season, 1932, 19 June 1933, Foreign and Political Department, 213-N, 1932, NAI (hereafter 1932 Report). 
The reports note in detail the cooperation the Pilgrim Department received from "charitable Muhammadans" based in Bombay and across India. These activities included distributing bread, rice, and meat and iced water to pilgrims. In 1925, the Begum of Bhopal sent money towards the Indigent Pilgrim Fund, and Haji Khuda Baksh from Lucknow decided not to perform the Hajj but instead gave his money to several hopeful pilgrims from Bukhara to go to Mecca. ${ }^{97}$ Private subjects and royal personages working together with the colonial government presented an idealized vision of relations between officialdom and India's colonial subjects. The reports also record the Pilgrim Department's monitoring of certain personages deemed notable; in 1932 a prince of Afghanistan and his retinue, a Sufi pir (holy man), and ex-Ottoman Sultan Abdul Hamid's grandson travelled from Bombay to perform the Hajj. ${ }^{98}$ This monitoring extended to the reports' extensive appendices of pilgrim numbers on incoming and outgoing ships, and tables showing the nationality of pilgrims for whom passports were issued in Bombay, down to the level of presidencies, princely states and non-Indian territories. ${ }^{99}$

These examples of orderly data and cooperation contrast starkly with passages in the reports that detail how various pilgrims challenged the colonial administration of the Hajj from Bombay. Several pilgrims complained about what the Protector termed "alleged defective arrangements" in connection with the medical inspection of female pilgrims, which was explained away in the report with an account of several officials inspecting the medical and sanitation facilities on the docks, pronouncing themselves "satisfied" with the arrangements. ${ }^{100}$ The overall impression of order in the 1932 report is broken by the description of the embarkation process, when "on several occasions there was a heavy rush and scramble for accommodation which the police found extremely difficult to control." These charges were led by pilgrim guides, who "made sudden rushes at the gangway forcing their way through the police lines."101

Poor pilgrims frequently occupied the Pilgrim Department's attention, being seen as a nuisance and financial cost to the government. Stowaways on board pilgrim ships were another aspect that clearly irritated the Protector. One example was an "aged Bokhari" that was discovered being carried by his son up the gangway in a large box in $1925 .{ }^{102}$ The pressures on British authorities

\footnotetext{
$97 \quad 1925$ Report.

$98 \quad 1932$ Report.

991925 Report; 1932 Report.

1001925 Report.

1011932 Report.

1021925 Report; 1932 Report.
} 
to save money as a result of the Great Depression meant destitute pilgrims received particular scrutiny. At the suggestion of the British Consul in Jeddah, the Pilgrim Department kept "a strict watch to find out if the destitute had any funds," but everyone apparently appeared penniless and were given money for train journeys to their homes across India. Slowly increasing numbers of destitute pilgrims, a result of the Great Depression, meant the government asked that any charities assisting poor pilgrims should give them enough money to return home in India. ${ }^{103}$ These examples suggest that in contrast to the overall impressions of order embedded in the reports, the colonial authorities faced numerous contestations of the rules and regulations surrounding the pilgrimage from Bombay by pilgrims, which possibly explains why, in his 1932 report, the Protector of Pilgrims was keen to emphasise the hard work of his staff "despite the many difficulties confronting them."104

\section{Non-Official British Sources on the Hajj}

As documents produced by state structures engaged in governance, official pilgrimage reports had distinctly different purposes, uses and influences to those of non-official British sources on official — and popular - understandings of the Hajj. While there are clear distinctions between some types of official and non-official sources and their authors, these two categories were sometimes far from hermetically sealed. A key example of this was Richard Burton's 1855-1856 travel account A Pilgrimage to Al-Medinah and Makka, based on his journey to the Hijāz to perform the Hajj in 1853 while on leave from the Indian Army. He subsequently became the British Consul in Damascus in 1869 largely as a result of his experience in the region. ${ }^{105}$ Burton's travel account appears to have a dual purpose. Firstly, it was designed to inform and entertain an educated reading public and bring him fame and fortune. Secondly, his account provided information to British officials on a religious ritual involving colonial subjects in a space that was off-limits to Christian Britons and put forward various suggested changes to British policy towards the Hajj. Burton's opinions on the subjects appeared to carry more weight than most, given the exhaustive details

\footnotetext{
1031932 Report.

1041932 Report.

105 A detailed analysis of Burton and the pilgrimage is Dane Kennedy, The Highly Civilised Man: Richard Burton and the Victorian World (Cambridge, MA: Harvard University Press, 2005), 58-92. On European travellers in Arabia, see R.L. Bidwell, Travellers in Arabia (New York: Hamlyn, 1976).
} 
his book provided, some eight hundred and fifty pages in two volumes, replete with footnotes and appendices.

Burton felt the government of India should "interfere" with the pilgrimage because he interpreted this flow of Muslims to the Hijāz as permanent emigration which would weaken India's labour productivity, an incorrect assessment. The explorer presented the ritual as a negative phenomenon for Muslims and British colonial rule: poor Muslims were motivated to perform the Hajj in "a fit of religious enthusiasm, likest to insanity" and the ritual "sends forth a horde of malcontents that ripen into bigots; it teaches foreign nations to despise our rule." 106 Burton believed that the continued presence of destitute Indian pilgrims stranded in the Hijāz, and the 1,500 Indians resident in Mecca and Jeddah, warranted an expansion of Britain's consular representation. He confidently felt that any opposition by the Sharif of Mecca to a British Muslim agent in Mecca "would soon fall to the ground."107 Charles Cole, Britain's Consul in Jeddah who Burton had spoken to, echoed a belief in the necessity of greater British involvement with the Hajj. But this viewpoint found little purchase among officials in India. India's Governor-General, the Earl of Dalhousie, was emphatic that the Hajj had nothing to do with British authorities; he believed the government had no right to prevent anyone from going on pilgrimage. ${ }^{108}$ These responses reflected the prevailing administrative doctrine in India, where administrative reforms were confined to what officials considered 'secular' affairs. ${ }^{109}$ It was not until the end of the nineteenth century when the principle of assisting destitute pilgrims was accepted by the consular and colonial authorities, and there was a British Indian Muslim representative in Mecca only for a brief period in 1919-1920. In this instance, then, Burton's nonofficial contribution to knowledge of the pilgrimage and related advocacy did not translate into official policy, and when these changes happened later, Burton was never referenced as the original proponent of these ideas.

Burton's travel account was responsible for bringing the pilgrimage to the attention of the English reading public. Popular knowledge of the Hajj was shaped by Burton and a succession of numerous newspaper articles in English

106 Richard Burton, Personal Narrative of a Pilgrimage to Al-Medinah and Meccah, Vol. 2 (London: Longmans and Co, 1855-1856), 185-186.

107 Ibid.

108 Secretary, Foreign Department, Government of India, to H.L. Anderson, Secretary Government of Bombay, May 5 1854, Foreign Department, Political—External Affairs—A, May 5, 1854, NAI.

109 Thomas R. Metcalf, Ideologies of the Raj (Cambridge: Cambridge University Press, 1994), 36. 
language newspapers during the imperial period. For British newspaper editors and journalists, the annual ritual possessed the requisite attributes to qualify as newsworthy-exotic, mysterious, a manifestation of religious exultation, a symbol of an unchanging East steeped in religion. Sometimes the Hajj was reported as part of a larger incident, such as a cholera epidemic or political turmoil in the Hijāz, but annual articles on the ritual followed a formula that changed little in this period, at least in the case of one newspaper, The Times of London. These articles reported with regularity that the Hajj was an annual ritual, obligatory for all Muslims who are able, which attracted thousands of Muslims from across the world who undertook various difficult journeys to reach Mecca, and outlined its component parts such as the tawäf, translated for English readers as circumambulation. ${ }^{110}$

From the 1920s, the rise of cinema meant knowledge of the Hajj percolated into a wider section of the British public through occasionally featuring in Pathé newsreels. The priorities and prejudices of Pathé editors, and the practicalities of gathering newsreel footage, meant that most news clips in the interwar period related to the Hajj covered the Egyptian mahmal. This was a pyramid-shaped palanquin carried on a camel that contained the kiswah, a series of large cloths made in Egypt, which were draped over the Ka'ba before each pilgrimage began. The clips focus on the maḥmal procession leaving Cairo, described by newsreaders as "a strange object ... the sacred litter of the Moslems," a "centuries-old Moslem ceremony," and called "the procession of the Sacred Carpet."111 These journalistic products were generally not designed to influence official policy and understandings of the Hajj, although it is probably true that many British officials whose work touched on pilgrimage-related matters read these articles or watched these newsreels.

Some newspaper articles, however, were written with the aim of changing understandings of the Hajj among the public and officials, with a sub-text that official policy should change. An incendiary article in the Times of India in

\footnotetext{
110 Times Online digital archive, search term 'pilgrimage Mecca', numerous articles from 1860-1940.

111 The Procession of the Sacred Carpet, 3 June 1926, 500.5, British Pathé online archive, http://www.britishpathe.com/video/the-procession-of-the-sacred-carpet/query/mecca. Last accessed: 4 November 2014; Sacred Carpet starts on its way to Mecca, 3 February 1938, 953.27, British Pathé online archive, http://www.britishpathe.com/video/sacred -carpet-starts-on-its-way-to-mecca/query/pilgrimage+mecca. Last accessed: 4 November 2014; Cairo 1946, 14 November 1946, 1416.26, British Pathé online archive, http://www .britishpathe.com/video/cairo-4/query/pilgrimage+mecca. Last accessed: 4 November 2014.
} 
1885 was one such example that focused on poor pilgrims' travels from India. Anonymously authored by a steamship captain on the Bombay-Jeddah route, it described how pilgrims from across South and Central Asia "tramp the best part of the way to Bombay in poor, miserable conditions." After being duped by pilgrim brokers, and examined by doctors from the Preventative Service in Bombay, they boarded over-crowded pilgrim ships that were often insanitary. The pilgrim traffic used a number of old steamships, and the competition meant ever-lower prices that encouraged poorer Muslims to make the voyage. The author felt pilgrims held little sense of fraternity with their co-religionists during their voyage; several nationalities were "mixed together, and one is growling at the other in his own language." After the pilgrimage's conclusion, he wrote, it was common to see many "lying on the beach under the shade of rocks, without money or clothes, without food and water, dying of disease and starvation." The writer thought the government's attitude to the Hajj was inconsistent; authorities recommended that pilgrims should have enough money for the journey, but simultaneously proclaimed non-interference in religious affairs. The Indian government's laissez-faire approach was criticised: "our government is afraid that if they do not allow our poor old natives of India to go on Hajj, they will keep them out of heaven."112

Perhaps unsurprisingly, the article had little effect in official circles. One official described it as full of "exaggerated verbiage and irrelevant matter" and refuted the article's various claims in painstaking detail to his superiors. The official was more strident regarding the anonymous author's idea of prohibiting pilgrims leaving without sufficient funds; this would be easily evaded, impossible to enforce, and would lead to "serious outcry" over interference with religious liberty. The author's identity was uncovered; Mr. Baldwin was a skipper on a ship owned by a Muslim firm. He was criticised for writing the article instead of approaching the government with his concerns. ${ }^{113} \mathrm{Mr}$. Baldwin, Richard Burton, journalists and cameramen were important transmitters of information regarding the Hajj to the English-speaking public, shaping popular conceptions of the ritual. While officials were certainly aware of these various non-official sources of knowledge on the Hajj, their influence in the official sphere, in terms of policy, seems rather limited, and these sources confirmed more than shaped officials' knowledge and conceptions of the pilgrimage.

\footnotetext{
112 The Times of India, October 31, 1885, 5 .

113 John Nugent, Secretary, Government of Bombay to Mackenzie, Secretary, Government of India, January 21 1886, General Department, 1885, Vol. 124, File 138, MSA.
} 


\section{Conclusion}

The sheer volume of colonial era records on the Hajj and the density of detail within them suggests, at first glance, a constant, all-seeing European gaze over the ritual. Yet closer analysis reveals the richness but also the silences, distortions, inaccuracies and ambiguities of these records. Despite first-hand observations by Muslims working for the British who were able to go to Mecca, their status as representatives of a colonial, Christian power, combined with the pressures of their day-to-day work, meant that what they recorded was only ever a partial picture. Their representations of the Hajj and pilgrims mirroredand shaped - the prejudices of their British employers. Comparing Muslim and non-Muslim writings on the Hajj from a number of official archives, it is striking, though unsurprising, that there are many similarities between Muslim and non-Muslim perceptions of pilgrims and various aspects of the Hajj. The ultimately partial nature of British official knowledge of the Hajj is even more starkly apparent when considering the figure of the British Consul in Jeddah, who often laboured under circumstances he thought intolerable, regarded his posting as a punishment, and his work on the pilgrimage as a sufferance.

Returning to the academic debate on the value and use of colonial knowledge discussed earlier in this chapter, the analysis of Hajj reports shows that we must appreciate the limits of this type of source and accept the validity of certain critiques of colonial knowledge. Yet such criticisms might also be applied to records produced by other officials working in and for other empires and states across the world and throughout history. Because colonialism and imperialism were such important forces in world history, we need to critically examine the sources left behind by those who were most closely involved in these disruptive phenomena. British pilgrimage reports are invaluable for understanding how colonial knowledge of the Hajj was produced and presentedwithin and beyond official circles, with a wide variety of audiences in a number of territories. The power of this knowledge in exercising control over pilgrims and the Hijāz itself remained limited. Through employing strategies of reading along and against the grain, this chapter has shown how these approaches provide new insights on colonial knowledge and the Hajj, such as the inner workings of consular and colonial bureaucracies, and enable the recovery of the words and agency of Muslim employees. These men were important producers and mediators of colonial knowledge on the Hajj; they highlight the plurality of authors in the colonial archive and its heterogeneous nature. Their voices in these archives provide a unique perspective on the Hajj. For the viewpoints of pilgrims themselves, we need to engage with a different set of sources, the travelogues of literate pilgrims, which while unsullied by filtration through the 
records of imperialism, are accompanied by their own set of theoretical, conceptual and analytical concerns as historical sources. ${ }^{114}$

\section{Bibliography}

Abir, M. "The 'Arab Rebellion' of Amir Ghalib of Mecca (1788-1813)." Middle Eastern Studies 7.2 (1971): 185-200.

Alavi, Seema. "Fugitive Mullahs and Outlawed Fanatics': Indian Muslims in Nineteenth-Century Trans-Asiatic Imperial Rivalries." Modern Asian Studies 45.6 (2011): 1337-1382.

al-Amr, Saleh Muhammad. The Hijaz under Ottoman Rule, 1869-1914. Riyadh: Riyadh University Publications, 1978.

Ballantyne, Tony. "Colonial knowledge." In The British Empire: Themes and Perspectives, edited by Sarah Stockwell. Oxford: Blackwell Publishers, 2008. 177-198.

Bayly, C.A. Empire and Information. Cambridge: Cambridge University Press, 1996.

Bidwell, R.L. Travellers in Arabia. New York: Hamlyn, 1976.

Bose, Sugata. A Hundred Horizons: the Indian Ocean in the age of global empire. Cambridge, MA: Harvard University Press, 2006.

Burton, Richard Francis. Personal Narrative of a Pilgrimage to Al-Madinah and Meccah, Vol. 2. London: Longmans and Co, 1855-1856.

Busch, Briton Cooper. Britain, India and the Arabs, 1914-1921. Berkeley, CA: University of California Press, 1971.

de Tassy, M. Garcin. Mémoire sur les particularités de la religion musulmane dans l'Inde d'après les ouvrages hindoustanis. Paris: De l'imprimerie royale, 1831.

Dirks, Nicholas B. "Foreword." In Bernard Cohn, Colonialism and its forms of knowledge: the British in India, ix-xviii. Princeton, NJ: Princeton University Press, 1996.

Euben, Roxanne L. Journeys to the other shore: Muslim and Western travellers in search of knowledge. Princeton, N.J.: Princeton University Press, 2008.

Freitag, Ulrike. "Helpless Representatives of the Great Powers? Western Consuls in Jeddah, 1830s to 1914." The Journal of Imperial and Commonwealth History 40.3 (2012): $357-381$.

Gottschalk, Peter. Religion, Science and Empire: Classifying Hinduism and Islam in British India. Oxford: Oxford University Press, 2012.

Iriye, Akira. Global and Transnational History: the past, present and future. Basingstoke: Palgrave Macmillan, 2013.

114 See the other chapters in this volume, and Roxanne L. Euben, Journeys to the other shore: Muslim and Western travellers in search of knowledge (Princeton, N.J.: Princeton University Press, 2008). 
Kennedy, Dane. The Highly Civilised Man: Richard Burton and the Victorian World. Cambridge, MA: Harvard University Press, 2005.

Laffan, Michael Francis. Islamic nationhood and colonial Indonesia: the umma below the winds. New York: Routledge Curzon, 2003.

Lapidus, Ira M. A history of Islamic societies. Cambridge: Cambridge University Press, 2002.

Low, M.C. "Empire and the Hajj: Pilgrims, Plagues and Pan-Islam, 1865-19o8." International Journal of Middle Eastern Studies 40 (2008): 269-290.

Metcalf, Thomas R. Ideologies of the Raj. Cambridge: Cambridge University Press, 1994. Miller, Michael. "Pilgrim's Progress: The Business of the Hajj." Past and Present 191 (2006): 189-228.

Mishra, Saurabh. Pilgrimage, politics and pestilence: the Haj from the Indian Sub-continent, 1860-1920. Delhi: Oxford University Press, 2011.

Motadel, David. "Islam and the European Empires." The Historical Journal 55.3 (2012): $831-856$.

Motadel, David. "Introduction." In Islam and the European Empires, edited by David

Motadel. Oxford: Oxford University Press, 2014. 1-34.

Motadel, David, ed. Islam and the European Empires. Oxford: Oxford University Press, 2014.

Peters, F.E. The Hajj: The Muslim pilgrimage to Mecca and the holy places. Princeton, NJ: Princeton University Press, 1994.

Özcan, Azmi. Pan-Islamism: Indian Muslims, the Ottomans and Britain 1877-1924. Leiden: Brill, 1997.

Raman, Bhavani. Document Raj: writing and scribes in early colonial south India. Chicago: The University of Chicago Press, 2012.

Robinson, Ronald, and John Gallagher. Africa and the Victorians: The official mind of imperialism. London: Macmillan, 1966.

Roff, William. "Sanitation and Security: The Imperial Powers and the Nineteenth Century Hajj." Arabian Studies 6 (1982): 143-161.

Rush, Alan, ed. Records of the Hajj: a documentary history of the pilgrimage to Mecca. Farnham, Surrey: Archive Editions, 1993.

Said, Edward. Orientalism. London: Routledge \& Kegan Paul, 1978.

Saurnier, Pierre-Yves. Transnational History. Basingstoke: Palgrave Macmillan, 2013.

Slight, John. The British Empire and the Hajj: 1865-1956. Cambridge, MA: Harvard University Press, 2015.

Spivak, Gaytari Chakravorty. "Can the subaltern speak?". In Marxism and the interpretation of Culture, edited by Cary Nelson and Larry Grossberg. Chicago: University of Illinois Press, 1988. 271-313.

Stoler, Ann Laura, Along the Archival Grain: Epistemic Anxieties and Colonial Common Sense. Princeton, NJ: Princeton University Press, 2009. 
Tagliacozzo, Eric. The Longest Journey: Southeast Asians and the Pilgrimage to Mecca. Oxford: Oxford University Press, 2013.

Trumbull, George R. An empire of facts: colonial power, cultural knowledge and Islam in Algeria, 1870-1914. Cambridge: Cambridge University Press, 2009.

Von Der Mehden, Fred. Two Worlds of Islam: Interaction between Southeast Asia and the Middle East. Gainesville, FL: University Press of Florida, 1993.

Wagner, Kim and Ricardo Roque. "Introduction: Engaging Colonial Knowledge." In Engaging Colonial Knowledge: reading European archives in world history, edited by Kim Wagner and Ricardo Roque. Basingstoke: Palgrave Macmillan, 2012. 1-34. 